\title{
IAMJ
}

INTERNATIONAL

AYURVEDIC

MEDICAL JOURNAL

\section{CRITICAL ANALYSIS OF RAJASWALA CHARYA IN RELATION WITH ATTENTION DEFICIT HYPERACTIVITY DISORDER (ADHD) IN CHILDREN - A SURVEY STUDY}

\author{
Shamna T.V. ${ }^{1}$, Venkatakrishna K.V ${ }^{2}$ \\ ${ }^{1} 3^{\text {rd }}$ Year PG Scholar, Department of PG Studies in Swasthavritta, Government Ayurveda Medical College, \\ Mysuru, Karnataka, India \\ ${ }^{2}$ Professor and HOD, Department of PG Studies in Swasthavritta, Government Ayurveda Medical College, \\ Mysuru, Karnataka, India
}

Corresponding Author: shamna.tv@gmail.com

https://doi.org/10.46607/iamj1709082021

(Published Online: August 2021)

Open Access

(C) International Ayurvedic Medical Journal, India 2021

Article Received: 31/07//2021 - Peer Reviewed: 11/08/2021 - Accepted for Publication: 12/08/2021

\section{Check for updates}

\begin{abstract}
Attention deficit hyperactivity disorder or ADHD is the commonest neurological disorder that affects the behaviour of children. ${ }^{1}$ World Health Organization put forth that, mental disorders are to shoot up by $50 \%$ in 2020 at international level. Indian studies rate the psychopathology among children as 5-15\% and ADHD has the highest incidence among all the other developmental disorders ${ }^{2}$. There is no disease by the name ADHD described in Ayurveda, but some conditions of abnormal behaviour can be screened from Ayurvedic literature like Anavasthita Chittatva ${ }^{3}$, Manovibhrama $^{4}$, Buddhivibhrama $^{5}$, Smritivibhrama $^{4}$, Sheelavibhrama ${ }^{6}$ Cheshtavibrama $^{7}$, and Acharavibhrama. It is found that emergence of the ADHD does not follow a single responsible factor ${ }^{7}$ and thus a single line of treatment does not cure $\mathrm{it}^{7},{ }^{2}$. The prevalence of ADHD is increased recently, and people started turning to alternative and complementary medicine especially Ayurveda, it is worthwhile to understand the probable aetiology to prevent the emergence of disease. It is known that the Rajaswala period is the largest and most important period among women's life and need to be healthy in this phase to have a better progeny. But in the present era, women are in hurry to reach the mainstream of society and under much physical and mental stress ends up with lack of care on their health even during menstruation which may lead to ill effect in later life ${ }^{8}$. This
\end{abstract}


study is to put light on the importance of following regimens and avoiding Apathyas especially during menstruation explained in Ayurvedic classics concerning ADHD.

Keywords: Rajaswala, ADHD, paricharya

\section{INTRODUCTION}

Rajaswala is the most influential and largest period among the three epochs of women's life- Bala, Rajaswala and Vrudha because it is the fertile period which is very much essential for reproduction and to have healthy offspring. ${ }^{9}$. The definition "raja Asti Asya iti" indicates the one who possesses rajas. It is a long period from menarche to menopause which includes both the Tharunee phase i.e. 16 to 32 years and Adhirudha phase i.e. 33 to 50 years. A female is called Rajaswala during the period of menstruation and the code of conduct to be followed and the care given during this period is called Rajaswala Paricharya $^{10}$. Proper care should be taken during this period as there are many physiological changes occur in women's body and is pitta predominant and hormone-regulating period. But in the present era, women are in hurry to reach the mainstream of society and under much physical and mental stress ends up with lack of care on their health even during menstruation which may lead to ill effect in later life. Attention-deficit/hyperactivity disorder (ADHD) is a neurodevelopment disorder that consists of a persistent pattern of inattention and/or hyperactive and impulsive behaviour that is more frequent and severe than expected in children of that age and development. ${ }^{11}$ World Health Organization put forth that, mental disorders are to shoot up by $50 \%$ in 2020 at the international level. Indian studies rate the psychopathology among children as 5-15\% and ADHD has the highest incidence among all the other developmental disorders. ${ }^{2}$ There is no disease by the name ADHD described in Ayurveda, but some conditions of abnormal behaviour can be screened from Ayurvedic literature like Anavasthita Chittatva, ${ }^{12}$ Manovibhrama $^{4}, \quad$ Buddhivibhrama ${ }^{5}$, Smritivibhrama ${ }^{4}$, Sheelavibhrama, ${ }^{4}$ Cheshtavibrama ${ }^{7}$, and Acharavibhrama. It is found that the emergence of ADHD does not follow a single responsible factor ${ }^{7}$ and a single line of treatment do not cure ADHD. ${ }^{2,7}$ As the prevalence of ADHD is increased recently and people turned to alternative and complementary medicine especially Ayurveda, it is worthwhile to understand the probable aetiology to prevent the emergence of disease. This study is to put light on the importance of following regimens and avoiding Apathyas especially during menstruation explained in Ayurvedic classics concerning ADHD.

Aim: To find the possible role of Rajaswala paricharya in the manifestation of ADHD

\section{Objective:}

1) To bring awareness about the importance of following Rajaswala charya

2) To analyze the role of Rajaswala paricharya in the manifestation of ADHD

\section{Materials and methods:}

- The literary study was done from Ayurvedic texts, modern literature and internet sources.

- Survey study: 45 Mothers of Children Diagnosed with ADHD have been surveyed with a questionnaire containing Rajaswalacharya as questions.

45 mothers of children with pre-diagnosed ADHD from OPD of Govt. Ayurveda Medical College and Hospital and Medical camps conducted in this regard are surveyed.

\section{Literature review on Rajaswala paricharya ${ }^{13}$ :}

Avoid

Divaswapna / Day sleep

Anjana / applying collyrium
After effect in progeny

Swapna Sheela

Andha 

(ADHD) In Children - A Survey Study

\begin{tabular}{|l|l|}
\hline Ashrupata or Rodana /weeping & Vikruthadrishti \\
\hline Snana /bathing & Dukhasheela \\
\hline Anulepana /using after paste & Dukhasheela \\
\hline Abhyanga/massage & Kushti \\
\hline Nakhachedana / nail cutting & Kunakhi \\
\hline Hasana / Laughing & Shyava dantha oshta thalu jihwa \\
\hline Pradhavana / Running & Chanchala \\
\hline Athikathana / Excessive talking & Pralapi \\
\hline Athishabdashravana / Excessive exposure to sound & Badhira \\
\hline Avalekhana / combing & Khalathi \\
\hline Anilayasa sevana / Exposure to Wind and exertion & Unmathi \\
\hline
\end{tabular}

\section{Result:}

No: of Mothers participated under Survey

45

No: Mothers remembers charya done during Rajaswala kala before conception

\begin{tabular}{|l|l|l|}
\hline Rajaswala charya & No: of mothers Practiced & Percentage of Mothers \\
\hline Divaswapna / Day sleep & 14 & $40 \%$ \\
\hline Anjana / applying collyrium & 9 & $26 \%$ \\
\hline Ashrupata or Rodana /weeping & 16 & $45 \%$ \\
\hline Snana / bathing & 35 & $100 \%$ \\
\hline Anulepana / using after paste & 0 & $0 \%$ \\
\hline Abhyanga / massage & 2 & $5 \%$ \\
\hline Nakhachedana / nail cutting & 14 & $40 \%$ \\
\hline Hasana / Laughing & 22 & $62 \%$ \\
\hline Pradhavana / Running & 13 & $37 \%$ \\
\hline Athikathana / Excessive talking & 8 & $22 \%$ \\
\hline Athishabdashravana / Excessive exposure to sound & 5 & $14 \%$ \\
\hline Avalekhana / combing & 32 & $91 \%$ \\
\hline Anilayasa sevana / Exposure to Wind and exertion & 8 & $23 \%$ \\
\hline
\end{tabular}




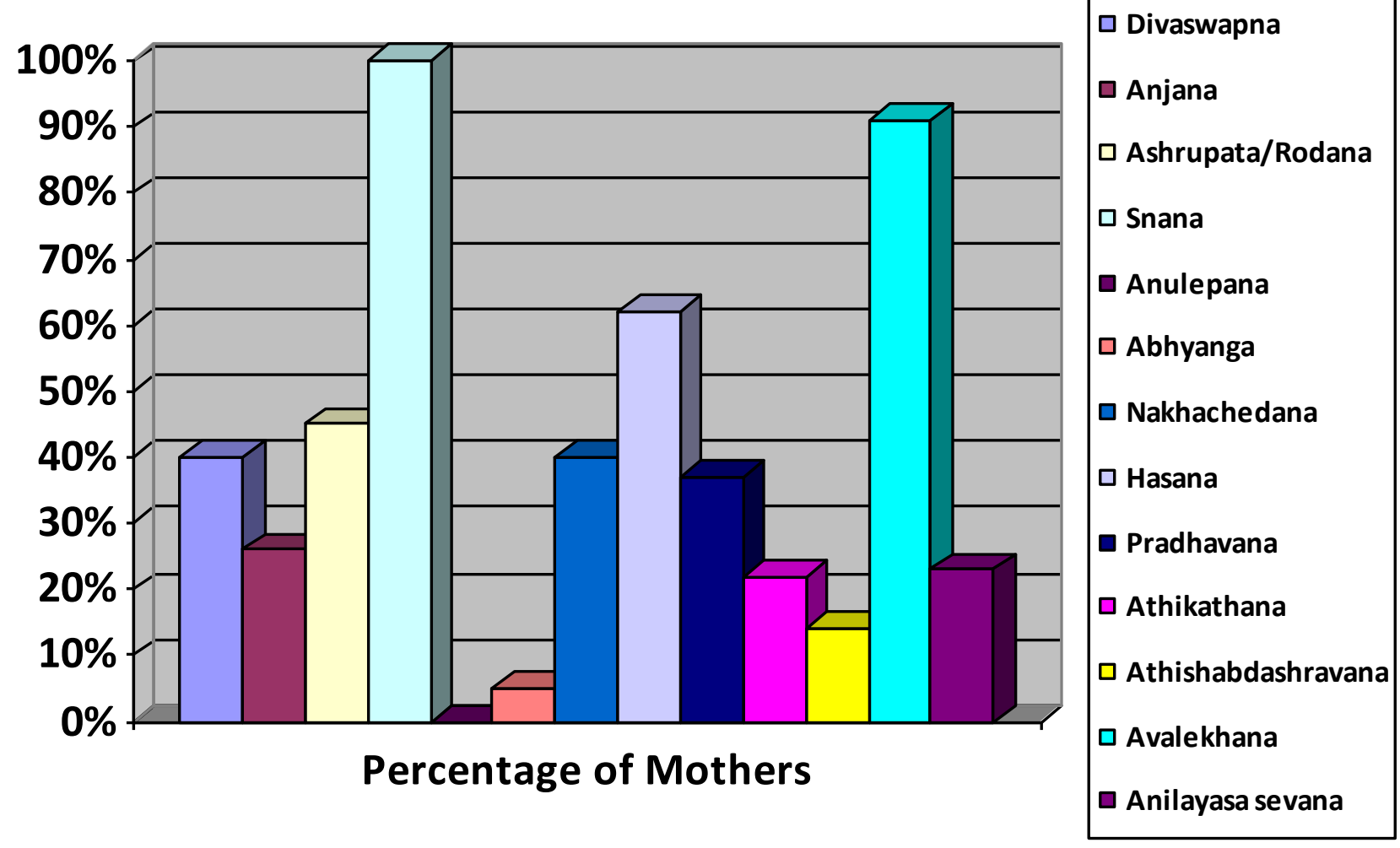

Among 45 mothers of children with ADHD who participated in the survey, $40 \%$ of them did Divaswapna during their Arthava kala, 26\% applied Anjana, $45 \%$ did Ashrupathana, only $5 \%$ did Abhyanga, $40 \%$ did Nakhachedana, $62 \%$ did Hasana, $37 \%$ did Pradhavana, $22 \%$ did Athikathana, $14 \%$ did Athishabda shravana, 91\% did Avalekhana, 23\% did Anilayasa sevana, all did Snana and none did Anulepana during their Arthavakala.

\section{DISCUSSION}

\section{Discussion on Literature review}

Thus, when Rajaswala charya is analyzed according to literature it is found that there may be serious consequences for the forthcoming progeny if not followed properly. Among these consequences, Chanchalata, Pralapa, Badhirata, Dukha sheelata and Unmathi are closely related to ADHD Symptoms. Athikathanam or Bahubhashanam (excessive talk), ${ }^{14}$ Udbrantha chithatwa (Unstable mind), Chanchalata to kriya, Mana ${ }^{15}$ and Swabhava
(Restlessness to body and mind and unstable behaviour) ${ }^{16}$, Badhirya (not seems to be listening to what is being said) ${ }^{17}$, Dukhasheelatha ${ }^{13}$ (emotional viability) etc are the symptoms present in child of the mother who followed apathyas during Rajaswala kala.

\section{Correlation with ADHD SYMPTOMS}

The Rajaswala kala apathya viharas practised by the mother will lead to complications or ill effects in progeny as explained in Shareera sthana of Susrutha samhitha. Among such viharas Hasana, Pradhavana, Athikathana, Athishabda shravana and Anilayasa sevana will lead to symptoms in progeny which are very similar to symptoms of ADHD. Chakrapani explains Badhirya as "Shabda maatrasya vaa asravanam" indicate difficulty or inability of hearing sound, words, or sentences. Some major symptoms under the inattention category of ADHD are" child seems as not listening to what is being said to him" and " child often fails to follow instructions or directions completely" 18 is coming under this heading. Badhirya is considered as vataja 
nanaatmaja vyadhi ${ }^{17}$ which also contributing to $\mathrm{ADHD}$ as it is a Vata pradhana disorder. Atikathana is excessive talking which is an important symptom under the hyperactivity subset of ADHD. Unmatto vatala: ${ }^{19}$ also indicates the excess activity of children or Chanchalatwa as the basic characteristics of Vata. Thus "child is excessive in talkativeness, easily excited and excessively restless, moves from side to side or up and down"18 etc symptoms which come under hyperactivity subset of ADHD can be concluded as Unmatha swaroopa of ADHD. Chanchalathwa or restlessness will be the nature of their mind and physical activity. These characteristics are very evident in children with ADHD as they are restless and excessively active in inappropriate situations. Pralapo asambandha bhashanam $^{20}$. Pralapa also conveys a similar meaning of irrelevant talk. "Child often talk excessively without judging or evaluating social restrictions", "child behaves without realizing the consequences", "child answers suddenly before questions have been completed and without thinking carefully", "child often behaves without realizing the consequences" 18 etc characteristics which come under the subset impulsivity of ADHD. Almost all children with ADHD suffer from emotional liability. Dukha sheelatha is the terminology very close to emotional liability which is said by resulted because of doing Snana and Anulepana in Rajaswala kala. When the statistics analyzed, $100 \%$ mothers had a history of doing snana in this period.

\section{Discussion on Survey Study:}

The survey study done suggest that the mothers of ADHD children had a history of practicing Apathya viharas during their Rahaswala kala. Among such viharas, $37 \%$ had a history of Pradhavana which would be a reason for chanchalathwa of shareera or hyperactivity in child similarly $22 \%$ had a history for Athikathana which is being explained as a reason for pralapa or vatala characters, $14 \%$ had a history of Athishabda shravana would be a reason for alpa matra shravana or ashravana, 23\% had a history of Anilayasa sevana which would be the main reason for unmada lakshanas and chanchalathwa of manas and all $100 \%$ had the history of snana and that would be a reason for Dukha sheelatha or emotional liability in children. The above symptoms are very much related to symptoms of ADHD.

\section{CONCLUSION}

Rajaswala charyas are the most neglected regimen in today's fast leading life. It is also found that many disorders are emerging newly in our country including ADHD. Many a time the reason behind is unknown. Some of the possible etiologies explained are hidden in between the lines of classical textbooks of Ayurveda. Thus, the reason for some symptoms seen in ADHD explained under Rajaswala apathyas are identified by literary search and found relevant to this context by survey study. This study is being done in small sample size and thus to validate these etiological factors a further study is recommended with large sample size.

\section{REFERENCES}

1. Singhal, Harish Kumar, Abhimanyu Kumar Neetu, and Moti Rai. "Ayurvedic approach for improving reaction time of attention deficit hyperactivity disorder affected children." Ауи 31.3 (2010): 338.

2. KC R, Dash PK. A Conceptual Review of Manas concerning Attention-Deficit Hyperactivity Disorder (ADHD) In Children. International Journal of Ayurvedic Medicine. 2017;8(3):105-9.

3. Vaidya Yadavji Thrikamji Acharya, Narayan Ram Acharya, Susrutha Samhitha of Ssrutha with the Nibandha Sangraha commentary, $8^{\text {th }}$ Edition, Varanasi, Chaukhambha orientalia,2005, Shareerasthana $1 / 6$

4. Vaidya Yadavji Thrikamji Acharya, Caraka Samhita by Agnivesha with the Ayurveda Deepika Commentary, Reprint edition, Varanasi, Chaukhambha orientalia,2015, Sutrasthana 8/4. And Ka.Sa.Su.p.67

5. Vaidya Yadavji Thrikamji Acharya, Caraka Samhita by Agnivesha with the Ayurveda Deepika Commentary, Reprint edition, Varanasi, Chaukhambha orientalia,2015, Shareera sthana1/21.

6. Vaidya Yadavji Thrikamji Acharya, Narayan Ram Acharya, Susrutha Samhitha of Ssrutha with the Nibandha Sangraha commentary, $8^{\text {th }}$ Edition, 
Varanasi, Chaukhambha orientalia, 2005, Shareerasthana $1 / 14$

7. Nilesh $\mathrm{M}$ Ingle, Ashwini $\mathrm{N}$ Ingle, Understanding the Concept of Attention Deficit and Hyperactivity Disorder in Ayurveda, Amravati (MH). Link-Journal of Sanskrit Samhita Siddhanta 2015, Vol 1:July - Sept ISSN: 2454-39267

8. Daudu OU, Ajiboye M, Ajala S, Buru ME. IOSR Journal of Dental and Medical Sciences (IOSRJDMS) e-ISSN: 2279-0853, p-ISSN: 2279-0861. Volume 16, Issue 5 Ver. VI (May. 2017), PP 34-35 www. iosrjournals. org.

9. Dr Pallavi Pai, Dr Sarita Bhutada, Dr Prasad Pandkar, Rajaswala Paricharya: Effect on Menstrual Cycle and Its Associated Symptoms, IOSR Journal of Dental and Medical Sciences (IOSR-JDMS) e-ISSN: 2279-0853, p-ISSN: 2279-0861.Volume 14, Issue 2 Ver. II (Feb. 2015), PP 82-87 https://www.iosrjournals.org/iosrjdms/papers/Vol14-issue2/Version-2/R014228287.pdf

10. Roshni KP, Concept of Rajaswala Paricharya (Care for Woman during Menstruation) in Ayurveda: Tool to Enhance Fertility*Corresponding author: Roshni KP, Asso Prof \& HOD, SJS Ayurveda College, Kriyasarira, India, Email: roshnibalesh@yahoo.co.in

11. WHO, International statistical Classification of Diseases and Related health problems (ICD-10), $10^{\text {th }}$ revision, Geneva, World Health Organization (1992).

12. Vaidya Yadavji Thrikamji Acharya, Narayan Ram Acharya, Susrutha Samhitha of Susrutha with the Nibandha Sangraha commentary, $8^{\text {th }}$ Edition, Varanasi, Chaukhambha orientalia,2005, Shareerasthana $1 / 6$

13. Vaidya Yadavji Thrikamji Acharya, Narayan Ram Acharya, Susrutha Samhitha of Ssrutha with the Nibandha Sangraha commentary, $8^{\text {th }}$ Edition, Varanasi, Chaukhambha orientalia,2005, Shareerasthana $2 / 25$

14. Vaidya Yadavji Thrikamji Acharya, Caraka Samhita by Agnivesha with the Ayurveda Deepika Commentary, Reprint edition, Varanasi, Chaukhambha orientalia,2015, Nidana sthana 7/6

15. Vaidya Yadavji Thrikamji Acharya, Caraka Samhita by Agnivesha with the Ayurveda Deepika Commentary, Reprint edition, Varanasi, Chaukhambha orientalia,2015, Sutra sthana 8/27

16. Vaidya Yadavji Thrikamji Acharya, Caraka Samhita by Agnivesha with the Ayurveda Deepika
Commentary, Reprint edition, Varanasi, Chaukhambha orientalia,2015, Shareera sthana 3/22

17. Vaidya Yadavji Thrikamji Acharya, Caraka Samhita by Agnivesha with the Ayurveda Deepika Commentary, Reprint edition, Varanasi, Chaukhambha orientalia,2015, Sutrasthana 20/1-11

18. Amoor $\mathrm{r}$ sing, /masrro jahan, Babu $\mathrm{p}$ Manual Diagnostic test of Attention deficit Hyperkinetic Disorder (DT:ADHD),Ranchi,Psychometrx,2015, p518,19

19. Vaidya Yadavji Thrikamji Acharya, Caraka Samhita by Agnivesha with the Ayurveda Deepika Commentary, Reprint edition, Varanasi, Chaukhambha orientalia,2015, Nidana sthana 7/6

20. Vaidya Yadavji Thrikamji Acharya, Narayan Ram Acharya, Susrutha Samhitha of Ssrutha with the Nibandha Sangraha commentary, $8^{\text {th }}$ Edition, Varanasi, Chaukhambha orientalia,2005, Shareerasthana 2/ 18-20

\section{Source of Support: Nil Conflict of Interest: None Declared}

How to cite this URL: Shamna T.V. \& Venkatakrishna K.V: Critical Analysis Of Rajaswala Charya In Relation With Attention Deficit Hyperactivity Disorder (ADHD) In Children - A Survey Study. International Ayurvedic Medical Journal \{online\} 2021 \{cited August 2021\} Available from: http://www.iamj.in/posts/images/upload/1711_1716.pdf 